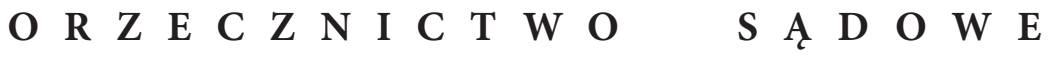

Ks. Ginter Dzierżon

Ius Matrimoniale

$31(2020) \mathrm{nr} 1$

DOI:10.21697/im.2020.31.1.08

Wydział Prawa Kanonicznego UKSW

ORCID: 0000-0002-5116-959X

\section{Problem konwalidacji zwykłej w wyroku c. Caberletti z 18 stycznia 2008 roku}

Treść: Wstęp. 1 Przebieg sprawy. 2. Motywy prawne. 3. Motywy faktyczne. 4. Uwagi do wyroku.

\section{Wstęp}

W edycji „Romanae Rotae Decisones” z reguły publikowane są wyroki, w których sprawy prowadzono z jednego z tytułów wad zgody małżeńskiej (kan. 1095-1103 KPK). W zbiorze tym wyjątkowymi są sentencje dotyczące konwalidacji zwykłej (kan. 1156-1160 KPK); taki charakter miała sprawa Brisbenen., rozstrzygnięta 18 stycznia 2008 roku. Orzeczenie c. Caberletti stanie się przedmiotem uwagi w tym opracowaniu ${ }^{1}$.

\section{Przebieg sprawy}

Strony procesu po krótkiej znajomości 21 sierpnia 1959 roku zawarły związek małżeński w kościele metodystycznym, ponieważ

1 Por. Dec. c. Caberletti z 18.1. 2008, RRDec., vol C., n. 1-8. 
dziewczyna należała do tej wspólnoty kościelnej²; jej matka żywiła odrazę do Kościoła katolickiego ${ }^{3}$.

Mężczyzna dla uspokojenia swego sumienia, za aprobatą żony, 31 marca 1960 roku uważnił związek, zawierając go z zachowaniem przepisów o formie kanonicznej. W maju 1961 roku kobieta przystąpiła do Kościoła katolickiego. Z tego związku narodziło się trzech synów ${ }^{4}$.

W 1981 roku, według mężczyzny, żona oznajmiła mu, że przed zawarciem ich związku utrzymywała kontakty z innymi mężczyznami. Wstrząśnięty tymi wiadomościami usiłował popełnić samobójstwo ${ }^{5}$.

Należy dodać, iż w historii małżeństwa stron istotną rolę odegrał również inny epizod: mąż był bardzo aktywny w życiu parafialnym, gdzie poznał schorowaną kobietę, w której zakochał się. Z tego powodu w lipcu 2002 roku doszło do separacji stron. 17 lutego 2004 roku mężczyzna wniósł skargę powodową do trybunału pierwszej instancji; 4 stycznia 2005 roku zawiązano litis contestatio z kilku tytułów: nieważności zastosowanej konwalidacji (kan. 1157, 1160 KPK; kan. 1134, 1137 CIC/17), poważnego braku rozeznania oceniającego po obu stronach (kan. 1095, n. 2 KPK; kan. 1081, 1082 CIC/17) a także błędu co do przymiotu osoby po stronie pozwanej (kan. $1097 \$ 2,1098$ KPK; kan. $1083 \$ 2$, n. 1 CIC/17) $)^{6}$.

Po przesłuchaniu stron, czterech świadków oraz zgromadzeniu odpowiednich dokumentów, 2 września 2005 roku wydano wyrok pro validitatae matrimonii ze wszystkich tytułów ${ }^{7}$. Po wniesieniu apelacji w trybunale drugiej instancji sprawę rozstrzygnięto pozytywnie jedynie $\mathrm{z}$ powodu nieważnej konwalidacji po stronie kobiety ${ }^{8}$. Po złożeniu przez nią apelacji do Roty Rzymskiej, 21 listopada tegoż roku

\footnotetext{
2 Szerzej na temat wspólnoty kościelnej zob. R.P. Heitzenrater, Wesley i ludzie zwani metodystami, tłum. K. Kuczma, Warszawa 2017.

3 Por. Dec. C. Caberletti z 18.1. 2008, n. 1.

4 Por. TAmże.

5 Por. TAmżE.

6 Por. Tamże.

7 Por. TAMżE.

8 Por. TAMżE.
} 
w trybunale tym ustalono zakres sporu $\mathrm{z}$ defektu formy kanonicznej'; 8 listopada 2007 roku zmodyfikowano go następująco: czy zawarte małżeństwo było nieważne z powodu nieważnej konwalidacji? ${ }^{10}$

\section{Motywy prawne}

Punktem wyjścia rozważań redaktora wyroku, podobnie jak $\mathrm{w}$ wielu innych wyrokach rotalnych, stało się pryncypium konsensualistyczne wyartykułowane w kan. 1057 \$1-2 KPK, którego geneza, jak przypomniał pones, tkwi w średniowiecznych źródłach (Mikołaj I, List do Bułgarów, Sobór Florencki, Dekret do Ormian) ${ }^{11}$.

Wiadomo już, że na poziomie Roty Rzymskiej w sprawie Brisbanen. najistotniejszym problemem była nieważność dokonanej konwalidacji, pozostająca w ścisłym związku z wypełnieniem przepisów o formie kanonicznej. Stąd też w n. 3 części in iure przedmiotem szczególnej uwagi audytora rotalnego stała się kwestia waloru tego formalnego komponentu struktury prawnej małżeństwa. Jednocześnie należy zauważyć, że bazę teoretycznoprawną analiz stanowiła teoria aktu prawnego ${ }^{12}$. Rozpoczynając je najpierw przywołał kan. 124 $\$ 1 \mathrm{KPK}$, w którym wśród elementów przedmiotowych wymaganych do ważności aktu, wymieniono komponent formalny - sollemnia ${ }^{13}$. W tym kontekście audytor rotalny przypomniał, że przepisy o formie kanonicznej wprowadzono na Soborze Trydenckim, opublikowanym 11 listopada 1563 roku Dekretem Tametsi, aby zapobiec zawieraniu

\footnotetext{
9 Por. TAmżE.

10 Por. TAMżE.

11 Por. TAmże. n. 2.

12 Por. G. Dzierżon, Niezdolność do zawarcia matżeństwa jako kategoria kanoniczna, Warszawa 2002, s. 25-60.

13 Por. G. Dzierżon, Niezdolność do zawarcia małżeństwa..., dz. cyt., s. 98-100; B. Ferme, Gli elementi dell'atto giuridico: essenza (motivazione, volontà e dichiarazione) e forma, w: L'atto giuridico nel diritto canonico, Città del Vaticano 2002, s. $89-102$.
} 
małżeństw tajnych ${ }^{14}$. Tym samym, zauważył sędzia rotalny, zobligowano katolików nie tylko do zawierania związków małżeńskich poprzez wyrażenie zgody małżeńskiej, ale również do uczynienia tego przed „obliczem Kościoła” (in facie Ecclesiae). Regulacje o formie kanonicznej znalazły się zarówno w Kodeksie pio-benedyktyńskim z 1917 roku (kan. 1094), jak i Kodeksie Jana Pawła II z 1983 roku (kan. $1108 \$ 1)^{15}$.

Odnosząc się do waloru prawnego tego zobowiązania katolików redaktor wyroku podkreślił, iż ustawom kościelnym podlegają wszyscy wierni ochrzczeni w Kościele katolickim lub do niego przyjęci, jeśli wyraźnie czego innego nie postanowiono. Zauważył też, iż takim wyjątkiem są m.in. przepisy o formie kanonicznej ${ }^{16}$. Celnie spostrzegł, że regulacje dotyczące tej formalności prawnej formy kanonicznej w Kodeksie z 1917 roku zostały w prowadzone na zasadzie wyjątku od prawa ogólnego. Popierając tę tezę wskazał na kan. 1099 \$1 CIC/17, zgodnie z którym: „Do zachowania formy kanonicznej zobowiązani byli: 1. Wszyscy ochrzczeni w Kościele katolickim i nawróceni z herezji i schizmy, ilekroć zawierali między sobą małżeństwo, chociażby ci lub tamci później od Kościoła odpadli; 2. Ci sami, o których wyżej, gdy zawierali małżeństwo z akatolikami ochrzczonymi, czy nieochrzczonymi, nawet za dyspensą od przeszkód odmiennego wyznania lub różności religii; 3. Członkowie Kościoła Wschodniego, jeśli zawierali małżeństwo z wiernymi Kościoła łacińskiego, zobligowanymi do zachowania formy kanonicznej; 4 . Z zachowaniem przepisu $\$ 1$, n. 1, akatolicy czy to ochrzczeni czy nieochrzczeni byli zobowiązani, jeśli zawieraliby małżeństwo między sobą, a nigdzie nie byli zobligowani do zachowania katolickiej formy kanonicznej". Następnie przytoczył analogiczny, obecnie obowiązujący kan. 1117 KPK o następującej treści: „Określona wyżej forma powinna być zachowana, jeśli przynajmniej jedna ze stron zawierających małżeństwo została ochrzczona

\footnotetext{
14 Na temat historii instytucji formy kanonicznej zob. L. BENDER, Forma iuridica matrimonii, Roma-Parigi-New York-Tournai (Belgio) 1960, s. 19-21.

15 Por. Dec. C. Caberletti z 18.01.2008, n. 3.

16 Por. TAmże, n. 4.
} 
w Kościele katolickim lub została do niego przyjęta i nie odstąpiła od niego formalnym aktem, z zachowaniem przepisów kan. $1127 \$ 2 ”$

Rozwijając tę myśl zwrócił uwagę, iż za wyjątkiem zawarcia małżeństwa w formie nadzwyczajnej (kan. 1098 CIC/17; kan. 1116 KPK) przepisom o formie kanonicznej nie czyni zadość zawarcie związku cywilnego przez wiernych, którzy prawnie są do tego zobligowani ${ }^{17}$.

Po czym audytor rotalny podjął kwestię waloru nieważności aktu wynikającego z pominięcia formy kanonicznej. Nawiązał do myśli Valesio De Paolisa zawartej w artykule „L'atto giuridico” (Studi Giuridici, t. 59, Città del Vaticano 2002, s. 29-41) rozróżniając między aktem nieistniejącym a aktem nieważnym lub prawnie nieskutecznym. Wyjaśniając tę kwestię skorzystał z treści opracowania „De convalidatione matrimonii (cc. 1133-1141)", autorstwa Urbano Navarrete zauważając, że akt prawny jest nieistniejący, jeśli brak jest elementu istotnego; jest zaś nieważny w znaczeniu simpliciter nullus, gdy brak jest jakiegoś elementu ustalonego przez prawo, przy założeniu, że elementy istotne zostały spełnione ${ }^{18}$.

Implementując te założenia teoretycznoprawne do kanonicznego systemu prawa małżeńskiego audytor w oparciu o kolejne opracowanie Navarretego „Consensus naturaliter sufficiens, sed iuridice inefficax. Limiti della sovranità del consenso matrimoniale” zwrócił uwagę, że w przypadku małżeństwa, niezaistnienie aktu może pochodzić $\mathrm{z}$ defektu konsensu małżeńskiego będącego causa efficiens et formalis consensus, bądź z defektu przedmiotu konsensu, który określił jako vere matrimonialis (causa materialis contractus); bardziej szczegółowo rozróżnił jeszcze między niezaistnieniem konsensu małżeńskiego a niezaistnieniem kontraktu małżeńskiego. Tłumacząc ten problem wyjaśnił, że gdy nie zaistniał konsens, wtedy nie zaistniał również kontrakt, ponieważ wystąpił zarówno brak przyczyny sprawczej, jak i przyczyny formalnej. Po czym dopowiedział, iż nie można też wykluczyć sytuacji, w której zaistniałby konsens małżeński, który

17 Por. TAMże.

18 Por. Dec. C. Caberletti z 18.01.2008, n. 4. Na ten temat zob. G. Dzierżon, Niezdolność do zawarcia małżeństwa..., dz. cyt., s. 52-60. 
generowałby kontakt, w którym pojawiłby się brak przedmiotu małżeńskości (matrimoniabile).

Potem przybliżył systemowe założenia generalne w kwestii nieważności małżeństwa zauważając, iż gdyby nawet nupturienci wyrazili prawdziwy konsens, to małżeństwo mogłoby być nieważne z powodu przeszkód pochodzących z prawa naturalnego bądź pozytywnego; w efekcie ważnie wyrażony konsens prawnie mógłby okazać się nieskuteczny ${ }^{19}$.

Kolejnym wątkiem rozważonym przez ponensa była kwestia defektu formy kanonicznej, który przykładowo mógłby zostać sprokurowany brakiem odpowiedniego uprawnienia u asystującego, którego według kan. 209 CIC/17 i kan. 144 KPK nie można uzupełnićc ${ }^{20}$. Audytor zauważył, iż taka sytuacja mogłaby zajść w przypadku zawarcia związku cywilnego katolików, bądź małżeństwa mieszanego katolika $\mathrm{z}$ akatolikiem zawartego bez dyspensy od formy kanonicznej ${ }^{21}$.

Odnosząc się do analizowanego kazusu związku cywilnego katolików sędzia rotalny spostrzegł, że w tym wypadku nie występuje defekt formy, ale absencja formy. Wyjaśniając tę kwestię ponownie posiłkował się myślą Navarretego, tym razem zaczerpniętą z komentarza do Dekretu Sygnatury Apostolskiej z 23 listopada 2005 roku (A proposto del Decreto del S.T. della Segnatura Apostolica del 23 novembre 2005), który tłumaczył, iż termin „defekt formy” oznacza defekt substancjalny, przykładem czego może być wspomniany brak kompetencji świadka urzędowego.

Opierając się na orzeczeniu c. Turnaturi z 30 kwietnia 1998 roku ponens stwierdził, iż nieważność małżeństwa powodowana defektem tej formalności prawnej może mieć podwójny charakter: może wynikać z totalnego braku substancjalnego formy kanonicznej, co może się zdarzyć, gdy jeden z nupturientów ochrzczony w wierze katolickiej

\footnotetext{
19 Por. Dec. C. Caberletti z 18.01.2008, n. 4.

20 Szerzej na ten temat zob. F. López Illana, La suplencia della facultad de asistir al matrimonio, w: R. Rodríguez-Ocaña (red.), Forma jurídica y marimonio canónico, Pamplona 1998, s. 93-158.

21 Por. Dec. C. Caberletti z 18.1. 2008, n. 4.
} 
lub nawrócony na wiarę katolicką, później wystąpił z Kościoła katolickiego (kan. $1099 \$ 1$, n. 1 CIC/17) zawierając związek cywilny lub małżeństwo „przed obliczem Kościoła”, ale nie w formie przepisanej prawem lub w formie wadliwej. Drążąc dalej tę tematykę redaktor wyroku nawiązał do przebiegu prac kodyfikacyjnych, przywołując przepis projektowanego kan. $1014 \$ 4$ Schematu z 1980 roku, w którym związek cywilny uznano za nieważny z powodu defektu formy; zauważył też, iż kanon ten skreślono przekonując, iż jego wprowadzenie mogłoby prowadzić do błędnych interpretacji ${ }^{22}$.

Odnosząc się do istniejącego stanu prawnego sędzia rotalny wskazał, iż było wolą prawodawcy (mens legislatoris), aby w przypadku związków cywilnych nie stosować konwalidacji zwykłej. Jego zdaniem ratio tego rozwiązania wynikało $\mathrm{z}$ faktu, iż w tym wypadku wierni katolicy nie zachowali przepisów o formie kanonicznej ${ }^{23}$. Jednocześnie zauważył, iż przyjęte rozwiązania w kanonicznym prawie małżeńskim były specyficzne, ponieważ w odniesieniu do pewnej kategorii małżeństw nieskutecznych, które katolicy wprawdzie zawarli, ale rozwiedli się, pragnąc zawrzeć małżeństwo z katolikiem, to wówczas stanu wolnego nie wykazuje się w trybie procesowym, lecz w trybie administracyjnym (Odpowiedzi Papieskiej Komisji do spraw Autentycznej Interpretacji Kanonów Kodeksu z 16 października 1919 roku ${ }^{24}$ oraz z 26 stycznia 1949 roku ${ }^{25}$, Odpowiedź Papieskiej Komisji do spraw Autentycznej Interpretacji Kodeksu Prawa Kanonicznego z 11

\footnotetext{
22 Por. TAMżE, n. 5.

23 Por. TAMżE.

24 Por. Pontificia Commissio ad Codicis Canones Authenticae InterpreTANDos, Responsa-16.10.1911, AAS 11(1919), s. 479. Pytanie zostało sformułowane następująco: „Si duo catholici, in loco certe ante hac obnoxio cap. Tametsi Con. Tridentini, vel post Decretum Ne temere matrimonium civile tantum inierunt, omisso ritu ecclesiastico, et obtento civili divorzio, novum in Ecclesia inire student matrimonium vel novum matrimonium initum, in foro Ecclesias convalidare". 25 Por. Pontificia Commissio ad Codicis Canones Authenticae InterpreTANDos, Responsa-26.01.1949, AAS 41(1949), s. 158: „An sub verbo «celebratum» can. $1015 \$ 4$ intellegi debent dumtaxat matrimonium coram Ecclesia celebratum. Affirmative", s. 131.
} 
lipca $\left.1984 \mathrm{roku}^{26}\right)$. W tym miejscu należy zauważyć, iż uwaga sędziego rotalnego dotyczyła związków zawartych w trzech konfiguracjach: po pierwsze, związków katolików zawartych jedynie cywilnie, którzy otrzymawszy rozwód cywilny, usiłowali zawrzeć lub zawarli nowy związek cywilny, pragnąc go sanować w kanonicznym porządku prawnym; po drugie, małżeństw katolika z akatolikiem zawartych w kościele sekty protestanckiej, którzy po rozwodzie pragnęli zawrzeć nowe małżeństwo z katolikiem; po trzecie, małżeństw apostatów z wiary katolickiej, którzy po rozwodzie cywilnym chcieli zawrzeć małżeństwo z katolikiem ${ }^{27}$.

Odnosząc się do statusu wymienionych kategorii związków, redaktor wyroku podkreślił, iż w tym wypadku nie występuje nieważność w znaczeniu matrimonium invalidum, gdyż nie posiadają one nawet fizjonomii małżeństwa kanonicznego ${ }^{28}$. W tym kontekście audytor jednak spostrzegł, mimo że niektórzy kanoniści stoją na stanowisku, że takie związki mogą być sanowane przy zastosowaniu konwalidacji zwykłej bądź konwalidacji w zawiązku, argumentując, iż w tych kazusach występuje defekt formy, a nie absencja formy (G.P. Montini) ${ }^{29}$.

W konstrukcji argumentacji in iure sędzia rotalny przywołał następnie n. 82 Adhortacji Apostolskiej „Familaris consortio”, w której papież Jan Paweł II odniósł się do specyficznej sytuacji małżeństw cywilnych katolików, następującymi słowami: „Coraz więcej jest takich

\footnotetext{
26 Por. Pontificia Commissio Codici Iuris Canonici Authenticae InterPRETANDO, Responsa-26.06.1984, AAS 41(1984), s. 747: „Utrum ad comprobandum statum liberum eorum qui, etsi ad formam adscicti, matrimonium attenterun coram civili officiali (...), necesario requiratur processus documnetalis de quo in can. 1686, an sufficiat invstigatio praematrimonialis ad normam Cann. 1066-1067. Negative ad Primum. Affirmative ad secundum". Szerzej na ten temat zob. C. Givliano, Il consenso naturalmente sufficiente espresso in assenza della forma canonica e la sua convalidadabilità, Roma 2015, s. 131-135.

27 Por. Dec. C. Caberletti z 18.01.2008, n. 5.

28 Por. Dec. c. Caberletti z 18.01.2008, n. 5. Szerzej na ten temat zob. G. DzierŻoN, Specyficzny status w kanonicznym porządku prawnym związków cywilnych zawieranych przez katolików z pomięciem formy kanonicznej, Kościoł i Prawo 8/21/ (2019), s.157-168.

29 Por. Dec. C. Caberletti z 18.01.2008, n. 5.
} 
przypadków, że katolicy ze względów ideologicznych lub praktycznych wolą zawrzeć tylko ślub cywilny, odrzucając lub przynajmniej odkładając ślub kościelny. Sytuacji tych ludzi nie można stawiać na równi z sytuacją tych, którzy współżyją ze sobą bez żadnego związku, tu bowiem istnieje przynajmniej jakieś zobowiązanie do określonej i prawdopodobnej trwałej sytuacji życiowej, chociaż często decyzji tej nie jest obca perspektywa ewentualnego rozwodu. Chcąc publicznego uznania ich związku przez państwo, pary te wykazują gotowość przyjęcia, obok korzyści także zobowiązań. Mimo to również i ta sytuacja nie jest do przyjęcia przez Kościół"30. Odnosząc się do tego dokumentu ponens zauważył, iż chociaż posiadał on charakter pastoralny, to jednak, jego zdaniem, z niego wynikało implicite, iż w odniesieniu do związków cywilnych katolików nie wyklucza się zastosowania uważnienia w zawiązku (kan. $1161 \S 1 \mathrm{KPK})$. W tym kontekście przywołał zapisy kan. 1159 \$1 i 1160 KPK wskazując, iż $\mathrm{w}$ regulacjach tych nie została wyeksponowana różnica między defektem formy a absencją formy; wskazał, iż operuje się w nich jednym terminem defectus formae ${ }^{31}$.

W oparciu o wymienione odpowiedzi Papieskich Komisji z 16 października 1919 roku, z 26 stycznia 1949 roku oraz z 11 lipca 1984 roku ponens celnie zauważył, iż wskutek pominięcia przepisów o formie kanonicznej katolicy nie mogą zawrzeć ważnego małżeństwa kanonicznego; w tym wypadku, jego zdaniem, można mówić jedynie o usiłowaniu zawarcia małżeństwa ${ }^{32}$.

W n. 6 przedmiotem zainteresowania audytora stała się instytucja uważnienia zwykłego (kan. $1133 \$ 1$ CIC/17; kan. $1156 \$ 1$ KPK). Stwierdził, iż jej istotnym elementem jest ponowienie zgody małżeńskiej (kan. 1134 CIC/17; kan. 1157 KPK). Trzeba podkreślić, iż redaktor

\footnotetext{
30 Por. Dec. C. Caberletti z 18.01.2008, n. 5; Jan Pawe€ II, Adhortacja Apostolska Familiaris consortio-22.11.1981, w: M. RomaneK (red.), Adhortacje Apostolskie Ojca świętego Jana Pawła II, t. 1, Kraków 2006, s. 204-205; JoAnnes Paulus II, Adhortatio Apostolica Familiaris consortio-22.11.1981, AAS 74(1981), s. 183.

31 Por. Dec. C. Caberletti z 18.01.2008, n. 5.

32 Por. TAMżE.
} 
wyroku w swych rozważaniach nie ograniczył się do przytoczenia stosownych regulacji, ale poszukiwał ratio legis tych zapisów posiłkując się z jednej strony opiniami kanonistów (F.M. Capello, M. Conte a Coronata, L. Miguéez Domínguez), z drugiej zaś jurysprudencją rotalną (dec. c. Wynen z 1 lipca 1940 roku, dec. c. Rogers z 21 stycznia 1969 roku, dec. c. Pompedda z 9 maja 1970 roku, dec. Funghini z 20 czerwca 1988 roku).

Skonstatował, iż w przypadku nieważności związku z powodu defektu formy idzie o zawarcie nowego małżeństwa. Wyjaśniając tę kwestię powołał się na opinię Alberto Bernárdeez Cantóna stwierdzając, iż inaczej jak to ma miejsce w przypadku przeszkód zrywających bądź wad konsensu zakłada się zaistnienie nowego konsensu, to w przypadku defektu formy postuluje się zawarcie nowego kontraktu (kan. 1137 CIC/17; kan. 1160 KPK). Zauważył też, iż w doktrynie przyznaje się relewantność nie tylko konsensowi aktualnemu, ale również wirtualnemu.

Konkludując stwierdził, iż zarówno w przypadku związku cywilnego, jak i w wypadku totalnej absencji formy konieczne jest, aby nupturienci aktualnie wyrazili zgodę małżeńską; w tym miejscu zauważył, iż nie wyklucza się również relewantności woli wirtualnej, która ma szczególne znaczenie przy stosowaniu sanatio in radice (kan. 1139 CIC/17; kan. $1161 \$ 1 \mathrm{KPK})^{33}$.

Kończąc spostrzegł, iż nieważna konwalidacja może być generowana m.in. symulacją. Może się bowiem zdarzyć, że nupturient nie będzie pragnął zawrzeć małżeństwo ${ }^{34}$.

\section{Motywy faktyczne}

Rozpoczynając konstrukcję uzasadnienia faktycznego wyroku ponens zauważył, iż kobieta wyznała, że za małżeństwo uznała związek zawarty u metodystów, dlatego dla niej mało istotne było zawarcie małżeństwa w świątyni katolickiej. Była ona jednak świadoma tego,

\footnotetext{
33 Por. TAmże, n. 6.

34 Por. TAMżE.
} 
iż stanowisko męża i jego rodziny w tej kwestii było odmienne, gdyż nalegali oni na zawarcie związku według przepisów katolickich, toteż w 1960 roku zadecydowała się na powtórne zawarcie małżeństwa zgodnie z obrzędami katolickimi. Ze względu na to, że rodzina męża nadal pejoratywnie postrzegała jej przynależność do wspólnoty kościelnej metodystów w 1961 roku podjęła decyzję o przystąpieniu do Kościoła katolickiego ${ }^{35}$.

Jak wiadomo, problemem kluczowym w sprawie Brisbanen. była kwestia ważności konwalidacji. Według audytora pozwana szczerze pragnęła (recto animo) zawrzeć małżeństwo „przed obliczem Kościoła”. Stąd też, jego zdaniem, implicite odnowiła zgodę małżeńską (implicite suum actum renovabit). Zauważył też, że gdy uświadomiła sobie, iż małżeństwo będzie konwalidowane, wówczas wyróżnila dwa okresy: czas zawarcia związku we wspólnocie metodystów oraz uważnienie małżeństwa w Kościele katolickim ${ }^{36}$.

Dowodząc, audytor rotalny przywołał uwagi obrońcy węzła małżeńskiego utrzymującego, że pozwana często i wyraźnie wskazywała, że chciałaby nowego i prawdziwego aktu woli poprzez przeprowadzenie konwalidacji. Odnosząc się do tych uwag audytor potwierdził intencję zawarcia prawdziwego małżeństwa. Argumentując nawiązał do oświadczenia kobiety przekonywującej, że oboje z mężem pragnęli tego związku. Zeznała też, iż kategorycznie wykluczała rozwód; nigdy nie odrzucała sakramentalności małżeństwa ${ }^{37}$.

Ze względów formalnych zawarcie małżeństwa stron nastąpiło 25 marca 1960 roku, po uprzednim uzyskaniu dyspensy od małżeństwa mieszanego. Wkrótce po zawarciu związku stron kobieta również wyznała, że miała aktualną wolę zawarcia małżeństwa z powodem ${ }^{38}$.

Na zakończenie redaktor wyroku odniósł się do kwestii symulacji (kan. 1086 CIC/17). W jego opinii domniemanie iuris tantum ujęte $\mathrm{w} \$$ 1 tego kanonu zostało obalone, ponieważ pozwana słowami wyraziła

\footnotetext{
35 Por. TAmże, n. 7.

36 Por. TAMżE.

37 Por. TAMŻE.

38 Por. TAMżE.
} 
zgodę małżeńską; należało zatem założyć, że jej wola wewnętrzna była zgodna z wolą zewnętrzną. Stąd też zdaniem sędziego rotalnego w tej sytuacji należało wykluczyć symulację ${ }^{39}$.

18 stycznia 2008 roku turnus rotalny pod przewodnictwem Jordana Caberlettiego wyrokował negatywnie, to znaczy nie orzeczono nieważności małżeństwa $\mathrm{z}$ powodu nieważnej konwalidacji ${ }^{40}$.

\section{Uwagi do wyroku}

Treści prezentowanego wyroku c. Caberletti dotyczą specyficznej problematyki, to znaczy ważności konwalidacji nieważnego małżeństwa z powodu niezachowania przez strony przepisów o formie kanonicznej. Pragnę zauważyć, iż w części prawnej rozstrzygnięcia ponens w sposób dogłębny ukazał problematykę waloru tej formalności prawnej, w odniesieniu do związku katolika zobowiązanego do zachowania tej formalności prawnej z akatoliczką ochrzczoną w wspólnocie metodystów. Należy dodać, iż w sprawie Brisbanen. bazy normatywnej nie stanowiły regulacje Kodeksu z 1983 roku, ale regulacje Kodeksu pio-benedyktyńskiego, ponieważ małżeństwo stron zostało zawarte pod jego rządami.

Odnosząc się do rozważań redaktora wyroku należy zauważyć, iż w pierwszej kolejności jego uwaga koncentrowała się na statusie związków cywilnych katolików, zawartych z pominięciem formy kanonicznej; następnie na zasadzie analogii odniósł się do związku w interesującej go konfiguracji. Uważam, iż zupełnie zasadnie, obrał taką metodę, gdyż stosowne odpowiedzi Papieskiej Komisji, a także ujawniona dokumentacja prac kodyfikacyjnych odnosiła się do związków cywilnych katolików; poza tym publikacje kanonistyczne w tej materii w głównej mierze dotyczą tej problematyki.

W sprawie Brisbanen. nieważność małżeństwa stron wynikała z tego powodu, że katolik zawarł małżeństwo u metodystów. Pragnę spostrzec, iż redaktor wprost nie podjął kwestii waloru nieważności

\footnotetext{
39 Por. TAMżE.

40 Por. TAmże, n. 8.
} 
tego związku. Pisał o tym operując kategorią usiłowania zawarcia małżeństwa. Otóż rzecz jest w tym, iż naruszenie dyspozycji kan. 1099, n. 2 CIC/17 skutkowało tym, iż małżeństwo nie było nieważne $\mathrm{w}$ sensie actus nullus, ale w sensie matrimonium inexistens. Taki status znalazł odzwierciedlenie w zasadzie, zgodnie z którą w przypadku rozpadu takich związków stanu wolnego nupturienta nie dowodzi się $\mathrm{w}$ trybie procesowym, ale w trybie administracyjnym (Odpowiedzi Papieskich Komisji z 16 października 1919 roku, z 26 stycznia 1949 roku oraz z 11 lipca 1984 roku).

W prezentowanej sprawie miała miejsce konwalidacja zwykła. Zgodnie z kan. 1137 CIC/17 w przypadku małżeństw zawartych z powodu braku formy, należało na nowo zawrzeć małżeństwo ${ }^{41}$. Z natury rzeczy część faktyczna prezentowanej rotalnej sentencji została poświęcona temu problemowi. Małżeństwo stron z zachowaniem formy kanonicznej zostało zawarte w świątyni katolickiej. Przy tym należy zauważyć, iż w sytuacji gdy powód pragnął uważnić związek, to wola jego zawarcia nie podlegała dyskusji. Przedmiotem dowodzenia stała się więc wola pozwanej, co do której istniały wątpliwości. Audytor wykazał, iż chciała ona tego małżeństwa; poza tym podzielała katolicką wizję małżeństwa w jej elementach istotnych. Również dowiódł, iż nie symulowała. Stąd też orzeczono ważność małżeństwa.

W tym miejscu pragnę jeszcze zwrócić uwagę na jeden fakt, mianowicie linię interpretacyjną obraną przez ponensa, Jak wiadomo status związku w konfiguracji, która stała się przedmiotem jego zainteresowania był traktowany jako matrimonium inexistens. Przeważająca doktryna utrzymywała, iż w takim kazusie nie można zastosować uważnienia zwykłego, ale jedynie uważnienie w zawiązku. Audytor rotalny jednak zajął inne stanowisko przekonując, iż instytucję tą można aplikować w interesującej go sytuacji, dlatego też w wyroku tym mówi się m.in. o relewantności woli wirtualnej czy też o odnowieniu konsensu. Należy spostrzec, iż w jego analizie implicite występuje rozumowanie typu: istnieje pewien związek między wolą

41 Por. A. RAva, Il requisito della rinnovazione del consenso nella covalidazione semplice dal matrimonio (can. 1157 \$ 2). Studio stolico-giuridico, Roma 2001, s. 199. 
zawarcia związku cywilnego a wolą zawarcia małżeństwa religijnego. W dowodzeniu badając wolę pozwanej wykazał, iż miała ona wolę zawarcia prawdziwego małżeństwa. Stąd też orzeczono ważność konwalidacji, a co się z tym wiązało ważność tak zawartego związku.

Na zakończenie pragnę poświęcić jeszcze chwilę uwagi marginalnej, aczkolwiek istotnej kwestii, mianowicie kobieta po konwalidacji małżeństwa w 1961 roku przystąpiła do Kościoła katolickiego. Pragnę podkreślić, iż decyzja nie zmieniła statusu związku stron.

\section{The problem of a simple convalidation in a judgment of c. Caberletti of the 18 January 2008}

\section{Summary}

The presented study is a commentary to the judgment of c. Caberletti of the 18 January 2008 regarding the validity of the convalidation on the Brisbanen. case. The author of the article analysed in detail the individual segments of the rotal judgment: the course of the case and the legal and actual motives, enriching his considerations in the footnotes used in the publication. He showed that in the doctrinal part, ponens was based on the theory of a legal act and on publications of a theoretical and legal nature, by Urbano Naverrete. He indicated that the rotal judges proved the validity of the convalidation, as it proved that the defendant has the will to contract a true marriage.

Słowa kluczowe: małżeństwo kanoniczne, konwalidacja małżeństwa, wyrok Roty Rzymskiej.

Key words: canonical marriage, convalidation of marriage, the judgment of the Roman Rota

\section{Nota o autorze}

Ks. Ginter Dzierżon - profesor zwyczajny prawa kanonicznego, kierownik Katedry Historii, Teorii i Norm Ogólnych Prawa Kanonicznego na Wydziale Prawa Kanonicznego UKSW, Obrońca Węzła Małżeńskiego Sądu Biskupiego Diecezji Gliwickiej. 